\title{
Hypoxia-induced chemoresistance in cancer cells: The role of not only HIF-1
}

\author{
Helena Doktorova, Jan Hrabeta, Mohamed Ashraf Khalil, Tomas Eckschlager
}

\begin{abstract}
Background. The aim of this review is to provide the information about molecular basis of hypoxia-induced chemoresistance, focusing on the possibility of diagnostic and therapeutic use.

Results. Hypoxia is a common feature of tumors and represents an independent prognostic factor in many cancers. It is the result of imbalances in the intake and consumption of oxygen caused by abnormal vessels in the tumor and the rapid proliferation of cancer cells. Hypoxia-induced resistance to cisplatin, doxorubicin, etoposide, melphalan, 5 -flouoruracil, gemcitabine, and docetaxel has been reported in a number of experiments. Adaptation of tumor cells to hypoxia has important biological effects. The most studied factor responsible for these effects is hypoxia-inducible factor-1 (HIF-1) that significantly contributes to the aggressiveness and chemoresistance of different tumors. The HIF-1 complex, induced by hypoxia, binds to target genes, thereby increasing the expression of many genes. In addition, the expression of hundreds of genes can be also decreased in response to hypoxia in HIF-1 dependent manner, but without the detection of HIF-1 in these genes' promoters. HIF-1 independent mechanisms for drug resistance in hypoxia have been described, however, they are still rarely reported. The first clinical studies focusing on diagnosis of hypoxia and on inhibition of hypoxia-induced changes in cancer cells are starting to yield results.

Conclusions. The adaptation to hypoxia requires many genetic and biochemical responses that regulate one another. Hypoxia-induced resistance is a very complex field and we still know very little about it. Different approaches to circumvent hypoxia in tumors are under development.
\end{abstract}

Key words: HIF-1, hypoxia, chemoresistance, hypoxia-induced chemoresistance

Received: December 22, 2014; Accepted with revision: May 7, 2015; Available online: May 19, 2015

http://dx.doi.org/10.5507/bp.2015.025

Department of Pediatric Hematology and Oncology, $2^{\text {nd }}$ Faculty of Medicine, Charles University in Prague and University Hospital Motol, Prague, Czech Republic

Corresponding author: Tomas Eckschlager, e-mail: tomas.eckschlager@lfmotol.cuni.cz

\section{INTRODUCTION - HYPOXIA-INDUCED CHEMORESISTANCE}

Hypoxia is a common feature of a solid tumor's microenvironment and represents an independent prognostic factor for a variety of human cancers. For the purposes of this paper, references to tumor hypoxia can refer to the tumor as a whole or any part thereof in which hypoxia create a microenvironment It is the result of imbalances in the intake and consumption of oxygen. This results from vascularization that is structurally and functionally abnormal, coupled with high proliferation rates in tumor cells ${ }^{1}$.

The negative impact of hypoxia on cancer cells relative to the efficacy of radio- and chemotherapy has been known for several decades and the survival rate of patients with severely hypoxic tumors is shorter than patients with less hypoxic tumours ${ }^{2}$. In radiotherapy, low oxygen levels prevent the formation of DNA strand breaks induced by radiation, and inhibits repair of DNA damage that induces genetic instability ${ }^{3,4}$. Hypoxia-induced resistance to cisplatin, doxorubicin, etoposide, melphalan, 5-flouoruracil, gemcitabine, and docetaxel has been previously reported in a number of tumor cell types ${ }^{5-23}$.

Hypoxia regulates approximately $1 \%$ of the genes that play a role in the signaling pathways that control various aspects of tumor progression ${ }^{24}$. Adaptation of tumor cells to hypoxic conditions has important biological effects and contributes to the aggressive nature of tumors and their dedifferentiation and chemoresistance. In this context, the most studied transcription factor is hypoxia-inducible factor-1 (HIF-1). HIF-1 is an important factor in the adaptation of cells to hypoxic environments, and significantly contributes to the aggressiveness and chemoresistance of number of different tumours ${ }^{5,7-9,15,19,21,25-30}$. However, these changes can be independent of HIF-1 ( ref. $^{26,31}$ ) In several cell types, hypoxia-induced drug resistance is unaffected or only partially reversed by HIF-1 inhibition, suggesting the existence of HIF-1 independent mechanisms of hypoxia-induced drug resistance. Other reasons for chemoresistance of cells in hypoxic tumors include acidosis, nutrient starvation that inhibits cell proliferation, increased interstitial fluid pressure, and low drug concentrations. Tumors that are hypoxic because of abnormal vascularization also have decreased drug bioavailability $^{32}$. Therefore, inadequate pharmacokinetics in these areas may reduce the effectiveness of anticancer drugs even though they are effective under hypoxic conditions or even inhibit HIF-1 $\alpha$. Furthermore, HIF-1 knockdown cells can normally grow and survive in hypoxic conditions $^{7,33}$. HIF-1 independent mechanisms of drug resistance in hypoxia are under-investigation, but are still rarely reported.

The aim of this review is to provide general information about the molecular basis of hypoxia-induced chemo- 


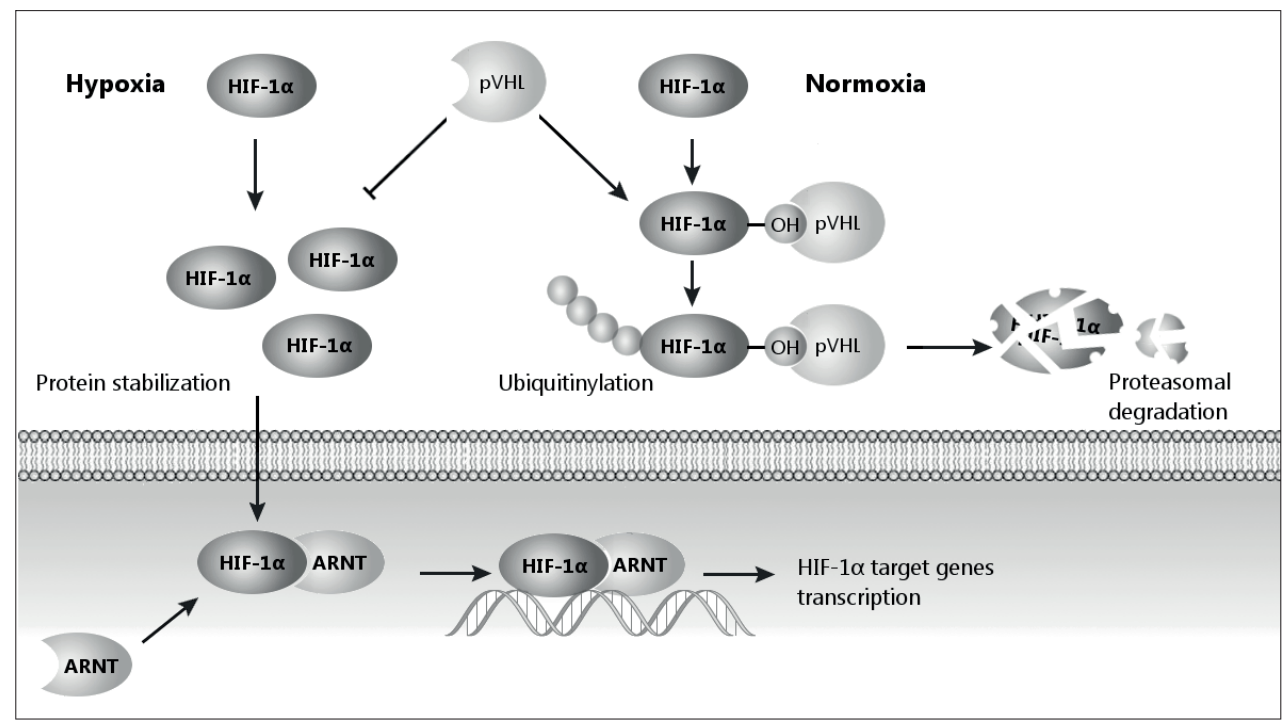

Fig. 1. Regulation of HIF-1 $\alpha$ stability in hypoxia and normoxia (adapted according to ref. ${ }^{41}$ ).

Table 1. Classification of HIF-1 regulated genes (modified according to ref. ${ }^{42,43}$ ).

\begin{tabular}{ll}
\hline Biological functions & Gene symbol/alias \\
\hline Transcription factors & TWIST1, Snail, ZEB1, ZEB2, ID2, SMAD7, PPAR $\gamma$, \\
& GATA1 \\
Histone modifiers & JMJD2B, JMJD2C, MLL1 \\
Enzymes & MMP1, MMP3, LOX, ADAMTS1, ACE, ACE2, XPA, \\
& HK1, HK2 \\
Receptors, receptor-associated kinase & CXCR4, CX3CR1, uPAR, PAI-1, 67-kDa laminin \\
& receptor, c-Met \\
Small GTPases, intracellular signaling molecules & VEGF, TGF- $\alpha$, TGF- $\beta 3$, IGF2, Cdc42, Rac1, RhoE, \\
& IRS-2 \\
Transporters & glut-1, glut-3, MDR1, VDAC1, transferrin, \\
& ceruloplasmin, IGF-BP1 - 3 \\
Membrane proteins & ANGPTL4, L1CAM, $\alpha 5$ integrin, CD151, CD24, \\
& CD147, Galectin-1 and 3, MUC1, Semaphorin 4D, \\
Scaffold protein, cytoplasmic protein & Caveolin-1 \\
Matricellular proteins & HEF1, Lipirin- $\alpha 4$ \\
\hline
\end{tabular}

resistance, focusing on diagnostic and therapeutic uses in clinical oncology.

\section{THE ROLE OF HIF-1}

HIF-1 is a master regulator of oxygen homeostasis with pleiotropic effects. It is a heterodimeric transcription factor composed of 2 subunits - an oxygen-regulated subunit HIF-1 $\alpha$ and a stable constitutively expressed nuclear factor, HIF-1 $\beta$ (aryl hydrocarbon receptor nuclear translocator, ARNT). Each subunit contains bHLH-PAS domains that mediate heterodimerization and DNA binding. Under normoxic conditions HIF-1 $\alpha$ is hydroxylated by prolyl hydroxylase (PHD) at prolines 402 and 564, and hydroxylated HIF-1 $\alpha$ recruits von Hippel-Lindau protein ( $\mathrm{pVHL}$ ), an E3 ubiquitin protein ligase, and is degraded by the $26 \mathrm{~S}$ proteasome after being targeted for ubiquitination $^{34-36}$. Recently, an additional mechanism has been recognized (by which HIF-1 $\alpha$ is degraded in lysosomes via chaperone mediated autophagy, including HSC70 and LAMP2A) that is independent of proteasome activity ${ }^{37}$. Under hypoxic conditions, cytosolic HIF- $1 \alpha$ is stabilized by inhibition of PHD-dependent enzymatic hydroxylation of proline residues and subsequently is translocated to the nucleus, where it binds to HIF-1 $\beta$ (ref. ${ }^{34-36}$ ). The HIF1 complex then binds to the hypoxia-response element (HRE) of the target genes (Fig. 1) (ref. ${ }^{35}$ ), which causes increased expression of hundreds of genes (Table 1) $\left(\right.$ ref. $\left.^{34}\right)$. In addition, the expression of many other genes is decreased in response to hypoxia (in a HIF-1 dependent manner), but without the detection of HIF-1 in the gene promotors $^{38}$. Moreover, tumor hypoxia (in a HIF-1 dependent manner) may upregulate receptor tyrosine kinases, 
including EGFR, through the repression of rabaptin-5 transcription $^{39}$. Many effects of HIF-1 are therefore made at the level of gene transcription; however, the direct interactions of HIF-1with other proteins, e.g. interaction between HIF-1 $\alpha$ and c-myc or p53, remain very important ${ }^{40}$.

During hypoxia, the pVHL-dependent proteasomal degradation of HIF-1 $\alpha$ does not occur. Thus, HIF-1 $\alpha$ is stabilized and transported to the nucleus where it forms a transcriptional complex with the ARNT/HIF-1 $\beta$ subunit. In the presence of transcriptional coactivators (not shown) HIF-1 complex can cause transactivation of the target genes leading to cell adaptation to hypoxic conditions.

Besides HIF-1 $\alpha$, there are two other transcription factors in this family of proteins, HIF- $2 \alpha$ and HIF- $3 \alpha$. The regulation and function of HIF- $3 \alpha$ is not yet entirely clear, it is the least-studied protein of these factors ${ }^{44}$. HIF-2 $\alpha$, also known as EPAS1 (Endothelial PAS domain-containing protein 1 ) is highly homologous to HIF-1 $\alpha$, i.e., they share very similar protein structure and the mechanism of their stabilization and action are also very similar ${ }^{45}$. Despite the similarities, HIF- $2 \alpha$ has several different transcriptional targets than HIF-1 $\alpha$, which can also be activated during severe hypoxia ${ }^{46}$. HIF- $2 \alpha$ can be detected at near physiological $\mathrm{pO}_{2}$ and its expression is tissue specific. Neuroblastoma cells in contact with blood vessels, and stromal cells surrounding the tumor have been shown to be HIF- $2 \alpha$ positive ${ }^{47}$. Overexpression of HIF- $2 \alpha$ is also observed in hemangioblastoma cells, which are very rich in blood vessels ${ }^{48}$. One specific HIF- $2 \alpha$ target gene is Oct4 , which encodes a transcription factor essential for the pluripotency of stem cells. Its activation is responsible for tumor cell dedifferentiation that has been demonstrated in neuroblastomas, breast cancer, and is probably the same in other tumours ${ }^{49-51}$. Activation of the Notch signaling pathway also participates in the loss of cell differentia$\operatorname{tion}^{52,53}$.

Moreover, HIF-1 regulates several miRNAs while other miRNAs target HIF-1. Changes in miRNA expres- sion, in response to hypoxia, are shown in Table 2. The interaction between miRNAs and HIF-1 may influence many signaling pathways important for angiogenesis, metabolism, apoptosis, cell cycle regulation, proliferation, metastasis, and resistance to anticancer therapy ${ }^{54}$.

\section{HIF-1 AND CHEMORESISTANCE}

The association of HIF-1 $\alpha$ overexpression with cell proliferation and poor prognosis has been observed in many human cancers ${ }^{35,36,55}$. Many of these HIF-1 inducible genes such as VEGF, Glut-1, MDR, and Bcl-2 directly or indirectly mediate chemoresistance ${ }^{19}$.Therefore, in a wide range of different tumor types, e.g. hepatocellular carcinoma, neuroblastoma, and lung cancer, inhibition of $\mathrm{HIF}-1 \alpha$ resensitizes cells to drug treatment in hypoxia and is then a valid target to reverse hypoxia-induced drug resistance e, $^{8,15,19,21,25,27-30,56}$. HIF-1 $\alpha$ accumulation has been associated with shorter survival in patients with early stage cervical, breast, ovarian, endometrial, oropharyngeal squamous cell carcinoma, and oligodendroglioma. Significant associations between HIF- $2 \alpha$ overexpression and increased patient mortality have been reported for other diseases, including non-small-cell lung cancer (NSCLC), neuroblastoma, astrocytoma, and head, and neck squamous cell carcinoma ${ }^{57}$.

Hypoxia-induced drug resistance in tumors has been reported for vincristine, doxorubicin, cisplatin, etoposide in neuroblastoma cells ${ }^{58,59}$; doxorubicin, vincristine, and actinomycin-D in rhabdomyosarcoma and Ewing's sarcoma cells ${ }^{15,26}$; cisplatin, doxorubicin, and etoposide in osteosarcoma $^{60}$; 5-fluorouracil, paclitaxel, doxorubicin, gemcitabine, and cisplatin in head and neck squamous cell carcinoma ${ }^{61,62}$; 5-fluorouracil and cisplatin in gastric cancer $^{63}$; cisplatin and doxorubicin in NSCLC (ref. ${ }^{8}$ ); and doxorubicin, etoposide, vincristine, and methotrexate in acute lymphoblastic leukemia ${ }^{64}$. The data came mainly from in vitro studies. Known HIF-1 transcriptional tar-

Table 2. Examples of changes of miRNAs expression in response to hypoxia (adapted according to ref. ${ }^{54}$ ). mRNAs can be upregulated as well as down-regulated, which reflects the complexity of miRNA in hypoxia regulation.

\begin{tabular}{|c|c|}
\hline Up-regulated miRNAs & The details of regulation \\
\hline miR-10b, miR-372/miR-373 & regulated by HIF-1 $\alpha$ (via TWIST) \\
\hline miR-103/miR-107 & repress DAPK and KLF4 (role in metastasis) \\
\hline miR-155 & regulated by HIF-1 $\alpha$, can also negatively influence the stability and activity of HIF-1 $\alpha$ \\
\hline $\operatorname{miR}-21$ & $\begin{array}{l}\text { regulated by Akt2 (via NF-kB and CREB) or RAS/ERK signaling, activate Akt and ERK1/2 } \\
\text { pathways leading to the elevation of HIF-1 } \alpha \text { and VEGF (via targeting PTEN) }\end{array}$ \\
\hline $\operatorname{miR}-210$ & $\begin{array}{l}\text { stabilize HIF-1 } \alpha \text { (via GPD1L repression), inhibit the expression of E2F3 and MNT (control } \\
\text { cell cycle progression), down-regulates VMP1 }\end{array}$ \\
\hline $\operatorname{miR}-424$ & suppress CUL2 (can stabilize HIF-1 $\alpha$ ) \\
\hline $\operatorname{miR}-519 \mathrm{c}$ & regulates HIF-1 $\alpha$ (angiogenesis) \\
\hline \multicolumn{2}{|l|}{ Down-regulated miRNAs } \\
\hline miR-17-92 & regulated by wild-type $\mathrm{p} 53$, stabilize HIF-1 $\alpha$ \\
\hline miR-107 & reduce the inhibition of HIF-1 $\beta$ (promotes angiogenesis) \\
\hline miR-20b, miR-200b & regulated by HIF-1 $\alpha$ \\
\hline miR-20b, miR-199 & stabilize HIF-1 $\alpha$ \\
\hline
\end{tabular}


Table 3. Overview of HIF-1 mediated drug resistance mechanisms (modified according to ref. ${ }^{32}$ ).

\begin{tabular}{lll}
\hline Cancer cell model & Drug/molecule & Resistance phenotype \\
\hline Breast cancer & etoposide & DNA damage inhibition \\
& methotrexate & drug efflux \\
paclitaxel, docetaxel & apoptosis inhibition \\
Colon cancer & driamycin & apoptosis inhibition \\
Fibrosarcoma & cisplatin, etoposide & apoptosis inhibition \\
Gastric cancer & multiple drugs & drug efflux; apoptosis inhibition \\
& 5-fluoruracil & apoptosis inhibition; senescence inhibition \\
Glioblastoma & adriamycin & drug efflux \\
Glioma & etoposide, doxorubicin & drug efflux \\
HCC & 5-fluoruracil & drug efflux \\
HeLa cells & etoposide & apoptosis inhibition \\
HNSCC & 4-HPR & apoptosis inhibition \\
Neuroblastoma & paclitaxel & apoptosis inhibition \\
OSCC & etoposide, vincristine & apoptosis inhibition \\
Prostate cancer & 5-fluoruracil, cisplatin & drug efflux; ROS decrease \\
& etoposide & DNA damage inhibition \\
flutamide & apoptosis inhibition \\
\hline
\end{tabular}

gets may induce drug resistance by affecting drug transporters, e.g. increased p-glycoprotein (MDR1, multidrug resistance 1) ( ref. $^{65}$ ); drug targets, e.g. decreased topoisomerase II (ref. ${ }^{25}$ ); or by changing the response to drugs, for instance by modifying drug-induced apoptosis ${ }^{58}$, reducing drug induced senescence ${ }^{9}$, or inducing autophagy in response to drugs (Table 3 ) $\left(\right.$ ref. $^{27}$ ). It has been shown that HIF-1 inhibition reverses multidrug resistance in colon cancer $^{66}$ and HIF- $1 \alpha$ knockout cells are more sensitive to cytostatics and irradiation than wild-types ${ }^{32}$.

\section{HIF-1 AS A PRO-OR ANTIAPOPTOTIC FACTOR}

Besides the protective responses, HIF-1 and/or hypoxia have also been shown to be either anti-apoptotic or proapoptotic, based on cell type and severity of hypoxia. More severe or prolonged hypoxia induces apoptosis that is, at least in part, initiated by the direct association of HIF- $1 \alpha$ and p53 (ref. ${ }^{67,68}$ ). Among proapoptotic genes regulated by HIF-1 are p53 (whose relation to HIF-1 is, however, very complicated and often seems to be controversial) and genes belonging to the Bcl-2 family of proteins - BNIP3, NIX and NOXA (ref. ${ }^{69,70}$ ).

BNIP3 (Bcl-2/adenovirus E1B $19 \mathrm{kDa}$ interacting protein 3 ) is expressed in the brain and skeletal muscles under normal conditions ${ }^{71}$, but its function is unknown. In most other tissues, BNIP3 expression is induced by HIF-1 under hypoxic conditions. BNIP3 has also been shown to induce cell type specific necrosis, apoptosis, and autophagy ${ }^{72,67}$. Proapoptotic functions of BNIP3 have been well documented in cardiomyocytes. On the other hand, while BNIP3 is expressed in hypoxic regions of tumors it fails to induce cell death. In ovarian cancer, the overexpression of BNIP3 truncated forms with mutations in bcl2-binding domain fail to induce cell death. Furthermore, the BNIP3 proapoptotic effect can be circumvented by EGFR signaling in epithelial cancer cells. Therefore, whether hypoxia-induced BNIP3 has a pro- or anti-apoptotic effect depends on the context and upon what genetic changes the cancer cells experience. From this point of view, hypoxia creates a strong selective pressure and selects cells with survival advantages and cell death resistance. Pro-apoptotic transcription factor p53 is considered to be the most common inhibitor of cellular proliferation as well as inducer of apoptosis. When cells sense a decrease in oxygen, HIF-1 can enhance the stability of p53 and these two transcription factors cooperate with each other to induce apoptosis that is p53-HIF-1-dependent ${ }^{68}$. The direct interaction between p 53 and HIF- $1 \alpha$ results in not only p53 stabilization but also inhibition of HIF-1-dependent transcription. This effect may explain the competition between p53 and HIF-1 for the p300 coactivator as well as MDM2 dependent degradation of HIF-1 $\alpha$ via formation of the p53/HIF-1/MDM2 complex ( ref. $^{73,74}$ ). However, the precise relationship of HIF-1 and p53 is still very complicated and unclear. The interaction between HIF-1 and p53 has been previously and comprehensively reviewed ${ }^{75}$. Based on the above-mentioned information, apoptosis or cell survival in hypoxic regions of tumors probably depends on the type of tumor and the presence or absence of genetic alterations that affect the balance between pro-apoptotic and anti-apoptotic roles of hypoxia-induced factors ${ }^{76}$. 


\section{OTHER FACTORS RESPONSIBLE FOR HYPOXIA-INDUCED CHEMORESISTANCE}

Other factors besides HIF-1 must be responsible for the cellular response to hypoxia and hypoxia-induced chemoresistance. A number of other cellular pathways are differentially regulated in hypoxia and may also contribute to hypoxia-induced drug resistance ${ }^{77-81}$. It has been shown that the suppression of HIF-1 $\alpha$ through gene knockdown or the use of small molecule inhibitors reduces resistance to cytostatics, such as cisplatin, etoposide, doxorubicin, and ellipticine, but does not suppress it completely ${ }^{20,33,59,60}$. The fact that in some cell lines (e.g. neuroblastoma, osteosarcoma, and lung adenocarcinoma) chemoresistance persists or is only partially reversed, despite HIF-1 being eliminated, points to alternative hypoxia-induced survival pathways $^{33}$.

Hypoxia selects more resistant cells having aggressive and metastatic phenotypes, which are often associated with poor prognoses, e.g., prostate cancer cells. This resistance to hypoxia-induced apoptosis may be due to the increased expression of anti-apoptotic factors including the IAP3 and Bcl-2 family of proteins and is independent on HIF-1 (ref. ${ }^{82}$ ). Inhibition of the phosphoinositol-3-kinase (PI3K) pathway, nuclear factor kappa-B (NF-kB), cycloxygenase-2 (COX-2), activator protein-1 (AP-1), cjun, Pim-1, and STAT-3 can reverse resistance to cytostatics in hypoxia, implying a role for these pathways in hypoxia-induced drug resistance ${ }^{10,18,22,23,33,77,83,84}$. However, the degree in which they are dependent on functional HIF-1 is uncertain.

Nuclear factor- $\kappa \mathrm{B}(\mathrm{NF}-\kappa \mathrm{B})$ is a ubiquitous transcription factor that is composed mainly of homo- or heterodimers of $\mathrm{p} 50$ and $\mathrm{p} 65$. NF- $\mathrm{NB}$ has been found to be overexpressed in tumors and to be activated by hypoxia $^{85,86}$. However, whether hypoxia-induced NF-kB activation contributes to tumor cell resistance or sensitivity to chemotherapy is still unknown. The contribution of $\mathrm{NF}-\kappa \mathrm{B}$ to chemoresistance has been reported in many cancers. Under resting conditions, NF- $\mathrm{kB}$ is held inactive in the cytoplasm, bound to NF- $\mathrm{B}$ inhibitors $(\mathrm{I} \kappa \mathrm{B} \alpha$, $\mathrm{I} \kappa \mathrm{B} \beta, \mathrm{I} \kappa \mathrm{B} \gamma$, and $\mathrm{I} \kappa \mathrm{Be}$ ) (ref. $\left.{ }^{87}\right)$. Upon stimulation with different substances, such as tumor necrosis factor alpha (TNF- $\alpha$ ), I $\kappa$ Bs are ubiquitinated and degraded and NF$\kappa \mathrm{B}$ is released and translocated to the nucleus ${ }^{88,89}$. NF- $\kappa \mathrm{B}$ then activates the transcription of target genes involved in angiogenesis, cell proliferation, and survival ${ }^{90}$. NF-kB up-regulates the expression of anti-apoptotic genes such as Bcl-2 (ref. ${ }^{91}$ ), cellular inhibitors of apoptosis (c-IAPs), and Bcl-xL (ref. ${ }^{92,93}$ ). However, other reports have suggested that NF- $\mathrm{kB}$ could also function as a tumor suppressor and the inhibition of its activity could counteract the effects of chemotherapy $^{94,95}$. Moreover, NF- $\kappa$ B subunits p50 and p65 have been shown to directly interact with HIF-1, during hypoxia, at a distinct element in the proximal promoter of the HIF-1 $\alpha$ gene $^{96,97}$, and these two transcription factors appear to share common regulatory pathways. Hypoxia may stop suppression of NF-kB activity through decreased PHD-dependent hydroxylation of IKK- $\beta$ (IкB kinase subunit beta) (ref. $\left.{ }^{98}\right)$. All the observations, taken together, leave no doubt that the cross-talk between NF-kB and HIF-1 is of an importance in the treatment of cancer.

Cyclooxygenase-2 (COX-2) and sphingosine kinase 2 (SphK2). It is thought that COX-2 inhibitors prevent the development of resistance to different cytostatics and that COX-2 overexpression induces increased multidrug resistance protein 1 (MRP1) expression in different cancer cells $^{99-102}$. Schnitzer et al. showed that COX-2 is upregulated under hypoxia in a HIF-1-independent fashion and sphingosine-1-phosphate (S1P) is responsible for COX-2 induction under hypoxia in A549 lung cancer cells $^{103}$. Simultaneous inhibition of HIF-1 and COX-2 strongly suppresses chemoresistance and the inhibition of only COX-2 decreases chemoresistance of cancer cells in hypoxia ${ }^{33}$. S1P formation and release are promoted by SphK2 expression, which is also responsible for enhancing its activity. Most likely, hypoxia causes an increase in SphK2 by achieving post-translational protein modification. However, the enhancing of mRNA transcription and translation or affecting mRNA stability is also possible ${ }^{104-106}$. The extracellular S1P activity leads to chemoresistance mediated via $\mathrm{S} 1 \mathrm{P} 1 / \mathrm{S} 1 \mathrm{P} 3$ receptors and $\mathrm{p} 42 / 44$ MAPK-dependent signaling pathways as well ${ }^{106}$.

Protein survival kinases PI3K and Akt. Phosphatidylinositol-3 kinases (PI3K) phosphorylate inositol phospholipids, generate the second messenger phosphatidylinositol $(3,4,5)$-trisphosphate $\left(\mathrm{PIP}_{3}\right)$ on the inner surface of the plasma membrane. Phosphatidylinositol $(3,4,5)$-trisphosphate $\left(\mathrm{PIP}_{3}\right)$ interacts with these phospholipids, causing its translocation to the inner membrane where it is phosphorylated and activated by pyruvate dehydrogenase kinases 1 and 2 (PDK1 and PDK2). Activated Akt modulates the function of numerous substrates involved in the regulation of cell survival, cell cycles, and cell growth ${ }^{107}$. The PI3K/Akt signaling pathway is frequently affected in human cancers, which can induce angiogenesis and oncogenic transition, both in a HIF-1dependent and -independent manner. Activation of PI3K and Akt protect cells against apoptosis and induces drug resistance during both normoxia and hypoxia. PI3K/Akt inhibition is able to reverse this resistance ${ }^{10,80}$. In pancreatic cancer, hypoxia-induced resistance to gemcitabine was shown to be also partially dependent on the MAPK (Erk) signaling pathway and NF- $\kappa \mathrm{B}$ (see above). Therefore, a combination of tyrosine kinase inhibitor with gemcitabine should be an effective therapy for pancreatic cancer. It has been shown that hypoxia increases phosphorylation of Akt ( ref. $^{10}$ ), but still, similar to other signals, the mechanism of hypoxia-mediated PI3K/Akt-dependent chemoresistance has not been laid out in detail.

Signal transducer and activator of transcription 3 (STAT3). It has been shown that enhanced glycolysis in hypoxic tumor cells is dependent on HIF-1 $\alpha$ up-regulation, while reduced mitochondrial activity is HIF$1 \alpha$-independent and likely caused by STAT3-mediated down-regulation of mitochondrial proteins. Constitutively active pro-oncogenic transcription factor STAT3 acts as a regulator of cell metabolism, inducing aerobic glycolysis and down-regulating mitochondrial activity, both in primary fibroblasts and in STAT3-dependent tumor cell 
lines. As a result, cells are protected from apoptosis and senescence while becoming highly sensitive to glucose deprivation ${ }^{108}$. STAT3 activation is significantly increased by the tumor hypoxia and is accompanied by increased ROS generation $^{23}$. Moreover, STAT3 directly regulates both cell-proliferation and pro-survival genes, both of which provide growth advantages to tumor cells by blocking proapoptotic genes ${ }^{23,109}$. Pharmacological inhibitors of STAT3 have been shown to significantly reduce cell proliferation capacity under hypoxic conditions and induce apoptosis in a variety of human cancer cells, e.g. breast, prostate, colon, and ovarian cancers ${ }^{110-112}$. Also, STAT3 inhibition partially overcame hypoxia-induced chemoresistance to cisplatin and taxol treatment ${ }^{23}$. Therefore, it seems that STAT3 activation might contribute to cellular resistance to anticancer drug-induced apoptosis. However, how STAT3 is activated in hypoxic cancer cells remains an intriguing question and it is obvious that STAT3 can act both HIF-1 $\alpha$ dependently or independently. It is reported that the VEGF promoter contains various transcription factor binding sites including STAT3 (ref. ${ }^{113}$ ) and HIF1 (ref. ${ }^{114}$ ). In hypoxia, STAT3 can interact with HIF-1 $\alpha$, increase its levels ${ }^{109}$ while both transcription factors control VEGF transcriptional activation leading to maximum activity and angiogenesis. Therefore, targeting STAT3/ HIF-1 $\alpha /$ VEGF signaling can be a potent anti-angiogenic strategy in tumors ${ }^{115,116 .}$

Pim kinases. The Pim serine/threonine kinases Pim-1, Pim-2, and Pim-3 regulate signaling pathways that contribute to tumor cell proliferation, expression of survival proteins and drug efflux transporters, and inhibit apoptosis. They affect tumor cell proliferation and survival through multiple mechanisms that include inhibition of major signaling pathways, interference with the activity of specific cell cycle molecules, and changes in gene expression $^{117}$. Overexpression of Pim kinases has been observed in patients with non-Hodgkin's lymphoma, leukemia, and prostate cancer ${ }^{118-121}$. The up-regulation of Pim kinases by hypoxia appears to be limited to Pim-1 (ref. ${ }^{117}$ ) and is HIF1 independent ${ }^{18,19}$. Hypoxia-induced expression of Pim-1 is associated with metastasis and worse treatment response, while inhibition of Pim-1 suppresses cell proliferation and migration, induces apoptosis, and increases sensitivity to cytotoxic drugs, e.g. to cisplatin, doxorubicin, and gemcitabine in pancreatic carcinoma ${ }^{18}$ or to docetaxel in prostate cancer cells ${ }^{122,123}$; this was found to be true under hypoxic conditions both in vitro and in vivo ${ }^{18,117}$. The Pim-1 expression level also correlates with tumor prognosis ${ }^{124}$.

Pim-1 induces resistance to anticancer drugs through stabilization of the mitochondrial transmembrane potential and regulates apoptosis, the cell cycle, and gene transcription by phosphorylating target proteins such as Bad, p21/waf1, c-Myb, and c-Myc (ref. ${ }^{18,125-130}$ ). Pim-1 down-regulates p27(Kip1) both at the transcriptional and post-translational level. p27(Kip1) is a cyclin-dependent kinase inhibitor 1B (CDKN1B) and its mutation or downregulation can lead to the loss of control over the cell cycle and to the uncontrolled cell proliferation ${ }^{131}$. Pim-1 may also affect the NF- $\mathrm{kB}$ pathway by phosphorylation and stabilization of RelA/p65, an important component of the NF- $\mathrm{BB}$ signaling pathway ${ }^{132}$, and facilitates signaling through the NF-kB pathway by down-regulating the expression of TNFAIP3/A20, a negative inhibitor of NF- $\kappa$ B signaling ${ }^{133}$. Pim-1 can also phosphorylate P-glycoprotein (MDR-1 gene product), which results in its protection from ubiquitination and proteasomal degradation. Its inhibition reverses resistance to doxorubicin in ovarian cancer cells that overexpress P-glycoprotein ${ }^{134}$. Experiments that directly link the effects of Pim-1 on NF- $\mathrm{kB}$ signaling and increased resistance to cytostatic drugs constitute a valuable and interesting field for further study ${ }^{117}$.

Carbonic anhydrases (CAs) are metalloenzymes that catalyze the interconversion of carbon dioxide and water to bicarbonate and protons to maintain the acid-base balance in blood and tissues, and to help transport carbon dioxide out of tissues. Hypoxia induces expression of carbonic anhydrase isoform IX (CA IX) via the HIF-1 pathway in many tumors. The role of CA IX in hypoxic tumor acidification processes has been demonstrated ${ }^{135}$. CA IX decreases extracellular $\mathrm{pH}$, disrupts cellular adhesion by degrading the catenin-cadherin complex or the integrin-mediated cell adhesion system, and induces upregulation of the genes involved in invasion and migration, and causes resistance to weakly basic cytostatics ${ }^{136,137}$. An explanation of the changes to the cell adhesion system appears to be linked to acidosis caused by carbonic acid produced by the CA IX-mediated catalytic transformation of carbon dioxide. It is assumed that CA IX inhibition, which normalizes tissue $\mathrm{pH}$, might cause tumor regression.

\section{METABOLISM, MITOCHONDRIA AND ATP}

The adaptation to hypoxia requires not only the above mentioned changes of expression, but also biochemical responses that counter-balance the decrease in energy supply from mitochondrial respiration. The metabolites influence expression of genes which regulate biochemical pathways that contribute to the metabolic signature of hypoxic cells ${ }^{138}$. Altered energy metabolism in cancer cells, such as decreased mitochondrial functions and enhanced aerobic glycolysis, is not only a fundamental phenotype of malignant tumors, but also play important roles during tumor progression, metastasis, and relapse $\mathrm{e}^{139,140}$ and is suspected to contribute to chemoresistance. The precise mechanisms, though, are still unclear ${ }^{141}$.

It has been shown that the increase in glucose uptake during hypoxia was not reversed by HIF-1 $\alpha$ silencing, indicating that bio-energetic needs can also be met by direct biochemical alterations without long-term genetic adaptation $^{138}$. ATP deprivation occurs in all types of cell death, during late-stage apoptosis, in autophagy, and during necrosis. Therefore, it is suggested that energy metabolism plays a critical role in the survival of cancer cells under stress $^{142,143}$. Moreover, drug-resistant cells were characterized by defective mitochondrial ATP production, elevated aerobic glycolysis, higher levels of intracellular ATP, and enhanced HIF-1-mediated signaling. Chemoresistant cells need faster ATP generating mechanisms to survive. They consume higher amounts of ATP via the endoplasmic 
reticulum enzyme UDPase ENTPD5, which in turn enhances aerobic glycolysis/fermentation ${ }^{144}$. Under these conditions, HIF-1 acts as a key glycolysis regulator and is up-regulated independently of oxygen levels ${ }^{141}$. HIF-1 also regulates mitochondrial functions. It has been shown that HIF-1 stabilization under hypoxia leads to the expression of PDK1 (ref. ${ }^{145}$ ) protein that phosphorylates and inactivates pyruvate dehydrogenase (PDH), and limits the conversion of pyruvate to acetyl-CoA in the mitochondria. Consequently, PDK1 induction decreases the citric acid cycle (TCA cycle) activity and reduces oxygen consump$\operatorname{tion}^{138}$.

Intracellular ATP levels are a core determinant in the development of acquired drug resistance of human colon cancer cells that harbor different genetic backgrounds. ATP induced resistance to oxaliplatin and to 5-fluorouracil can be seen in colorectal cancer cells. Conversely, depleting ATP by cell treatment with a glycolysis inhibitor, sensitizes cells resistant to oxaliplatin and also increased sensitivity to 5 -fluorouracil ${ }^{141}$.

It seems that under hypoxia, autophagy is required to support ATP production in addition to glycolysis and its inhibition might be used to selectively target hypoxic regions of tumors. Based on the above mentioned, an understanding of metabolic adaptations under hypoxia could reveal novel pathways that, if targeted, might lead to specific death of hypoxic regions while sparing normal cells that are rarely exposed to hypoxia. Mitochondria are the major oxygen consumers in the cell and are in the heart of several biochemical pathways involved in both energy production and generation of anabolic intermediates that are required for proliferation. Therefore, changes in mitochondrial function under hypoxia are likely to contribute to the altered metabolic profile of cells, making mitochondria important oxygen sensors. They can respire at very low oxygen levels and the rate of respiration of cells adapted to chronic hypoxia demonstrates that they retain active respiration, though at significantly reduced rates. Still, while genetic reprogramming during hypoxia has been characterized and many players in this process have been identified, the contribution of mitochondria to the hypoxic response is remains uncertain ${ }^{138}$.

\section{SIDE POPULATION AND CD133}

Cancer stem cell (CSC) models propose that tumors consist of a variety of cells with different proliferative and tumorigenic capacities. According to this theory, small populations of CSC have been suggested as drivers of tumor growth and are responsible for resistance to therapy, recurrence, and metastasis. In hypoxic tumors, CSCs are thought to be regulated by HIF- $1 \alpha$ and HIF- $2 \alpha$ for survival and protection of tumor growth ${ }^{146}$. CD133 is one of the most important markers for CSC in a variety of solid tumors. It has been reported in glioma cells that the number of CD133+ cells (CSC) (ref. ${ }^{147}$ ) or expression of CD133 in both SCLC and NSCLC cells ${ }^{148}$ was correlated with hypoxia-induced increase of HIF-1 $\alpha$. In pancreatic cancer cells, effects of hypoxia on up-regulation of CD133 was diminished after knocking down HIF-1 $\alpha$ (ref. $\left.{ }^{149}\right)$. Another study suggested that laryngeal cancer cells, subjected to hypoxia followed by normoxia, exhibited enhanced capacities for proliferation, invasion, sphere, and colony formation in comparison with cells which were maintained consistently under normoxia. These events were associated with an increasing CD133+ fraction denoting regulation of cancer stem cells by hypoxic microenvironments ${ }^{150}$. Moreover, Zhu et al. has demonstrated the role of HIF-1 in intermittent hypoxia on promoting the metastatic ability and invasiveness of CD133+ pancreatic cancer stem-like cells ${ }^{151}$.

Even though, most of the literature data shows the upregulation of CD133 during hypoxia, controversy of the regulatory mechanisms of CD133 expression via mTOR signaling and HIF- $1 \alpha$ in cancer cells might lead insights into the role of mTOR and oxygen-sensitive intracellular pathways in the maintenance of stemness in CSC (ref. ${ }^{152}$ ). It is possible to speculate that in some tumors, one of the mechanisms for hypoxia-induced resistance, may be induction of CSC.

\section{FUTURE PERSPECTIVES}

Targeting hypoxic cells within solid tumors seems to be a promising treatment modality to overcome resistance and prevent recurrence ${ }^{153}$. Many different approaches to overcome hypoxia-induced chemo- and/or radioresistance, including inhibitors of HIF-1, or hyperoxia, have been developed.

The first clinical studies focused on diagnosis of hypoxia and on the inhibition of hypoxia-induced changes in tumor cells have begun to yield results. Hu et al. have tested (18)F-fluoroerythronitroimidazole PET/CT that uses an assessment of tumor hypoxia to evaluate the prognosis on a group of thirty-two NSCLC patiens ${ }^{154}$. A clinical study examining antisense oligodeoxynucleotide binding HIF- $1 \alpha$ showed a decrease in HIF-1 protein levels and mRNA levels in some of its target genes in tumor cells ${ }^{155}$. Kummar et et al. proved that topotecan can decrease expression of HIF-1 $\alpha$ and some HIF-1 target genes like VEGF and GLUT-1 in solid tumors ${ }^{156}$. Other clinical studies have shown that celecoxib, a selective COX-2 inhibitor, decreased tumor cell proliferation, microvessel density, angiogenesis, HIF-1 levels, and enhanced apoptosis in prostate cancer ${ }^{157}$. The newly developed prodrug TH-303 (which consist of 2-nitroimidazole covalently linked to brominated isophosphoramide mustard i.e. the prodrug) and which, under hypoxic conditions, is converted into brominated isophosphoramide mustard (i.e. the active cytotoxic drug) seems to be promising. Phase I clinical trials with this drug have already been completed ${ }^{158}$.

Studies using hyperbaric oxygen therapy (HBOT) with chemotherapy have shown synergistic effects both in vitro and in vivo (for review see ref. ${ }^{159}$ ). Moreover, clinical studies in patients with gliomas ${ }^{160}$ and NSCLC (ref. ${ }^{161}$ ) have shown promising results, and several studies with the combination of HBOT and radiotherapy have been also performed ${ }^{162}$. However, this approach is still in its 
infancy and a number of questions, e.g. a sequence of individual modalities, duration, and intensity of HBOT need to be resolved.

\section{CONCLUSIONS}

In this review we have summarized the most important factors and pathways that contribute to hypoxia-induced chemoresistance in cancer cells. The adaptation to hypoxia requires many genetic and biochemical responses that regulate one another, revealing that hypoxia-induced resistance is a very complex and intricate field about which we still know very little. Since hypoxia is closely associated with chemo- and radioresistance, different approaches are continuously being developed in an effort to circumvent hypoxia-induced resistance.

\section{ABBREVIATIONS}

AP-1, Activator protein-1; ARNT, Aryl hydrocarbon receptor nuclear translocator; Bad, Bcl-2-associated death promoter; Bcl-2, B-cell lymphoma 2; Bcl-xL, B-cell lymphoma-extra-large; bHLH-PAS, basic helix-loop-helix period circadian protein $\mathrm{Ah}$ receptor nuclear translocator protein and single-minded protein; BNIP3, Bcl-2/adenovirus E1B $19 \mathrm{kDa}$ interacting protein 3; CA IX, Carbonic anhydrase isoform IX; c-Myb, myeloblastosis family of transcription factors; c-myc, v-myc avian myelocytomatosis viral oncogene homolog c; COX-2, Cycloxygenase-2; CDKNI1B, Cyclin-dependent kinase inhibitor 1B; EGFR, Epidermal growth factor receptor; EPAS1, Endothelial PAS domain-containing protein 1; Glut-1, Glucose transporter 1; HBOT, Hyperbaric oxygen therapy; HIF-1, Hypoxia-inducible factor-1; HRE, Hypoxia-response element; HSC70, Heat shock cognate protein 70; IAP31, inhibitor of apoptosis 31; c-IAPs, Inhibitors of apoptosis; $\mathrm{I} \kappa \mathrm{B} \alpha$, I $\kappa \mathrm{B} \beta$, I $\kappa \mathrm{B} \gamma$, and $\mathrm{I} \kappa \mathrm{B} \varepsilon, \mathrm{NF}-\kappa \mathrm{B}$ inhibitors $\alpha, \beta, \gamma$, and $\varepsilon$; LAMP2A, Lysosome-associated membrane protein 2; MDM2, Mouse double minute 2 homolog; MDR, Multiple drug resistance gene; MRP1, Multidrug resistance protein 1; mTOR, Mammalian target of rapamycin; NF- $\kappa \mathrm{B}$, Nuclear factor-kB; NIX, Nip3-like protein X; NSCLC, Non-small-cell lung cancer; Oct-4, Octamer-binding transcription factor 4; p21/waf1, Cyclin-dependent kinase inhibitor 1; PDK1 and PDK2, Pyruvate dehydrogenase kinases 1 and 2; PDH, Pyruvate dehydrogenase; PET/ CT, Positron emission tomography-computed tomography; PHD, Prolyl hydroxylase; PI3K, Phosphoinositol-3kinase; Pim-1, Pim-2, and Pim-3, Pim serine/threonine kinases 1, 2 and 3; PIP , Phosphatidylinositol (3,4,5)-trisphosphate; RelA/p65, Nuclear factor NF-kappa-B p65 subunit; S1P, Sphingosine-1-phosphate; SCLC, Small-cell lung cancer; SphK2, Sphingosine kinase 2; STAT3, Signal transducer and activator of transcription 3; TCA cycle, Citric acid cycle; TNFAIP3/A20, Tumor necrosis factor, alpha-induced protein 3; TNF- $\alpha$, Tumor necrosis factor $\alpha$; VEGF, Vascular endothelial growth factor; VHL - von Hippel-Lindau protein.

\section{ACKNOWLEDGMENT}

Supported by Charles University in Prague, project GA UK No 620612 and by the Ministry of Health of the Czech Republic for conceptual development of research organization 00064203 (University Hospital Motol, Prague, Czech Republic).

Author contributions: JH: wrote the chapters "Hif-1 as a pro- and anti-apoptotic factor" and "Other factors responsible for hypoxia induced chemoresistance"; MAK: wrote the chapter "Side population and CD133"; TE: wrote the chapters "Future perspectives" and "Conclusions" and final revision; HD: wrote all other chapters. All co-authors participated in the conception of the manuscript and revised the whole manuscript.

Conflict of interest statement: The authors state that there are no conflicts of interest regarding the publication of this article.

\section{REFERENCES}

1. Wouters BG, Van Den Beucken T, Magagnin MG, Lambin P, Koumenis C. Targeting hypoxia tolerance in cancer. Drug Resist Updat 2004; 7:25-40.

2. Mehlen P, Puisieux A. Metastasis: a question of life or death. Nat. Rev. Cancer 2006;6:449-58

3. Bindra RS, Crosby ME, Glazer PM. Regulation of DNA repair in hypoxic cancer cells. Cancer Metastasis Rev 2007;26:249-60.

4. Unruh A, Ressel A, Mohamed HG, Johnson RS, Nadrowitz R, Richter E, Katschinski DM, Wenger RH. The hypoxia-inducible factor-1 alpha is a negative factor for tumor therapy. Oncogene 2003;22:3213-20.

5. Brown LM, Cowen RL, Debray C, Eustace A, Erler JT, Sheppard FCD, Parker CA, Stratford IJ, Williams KJ. Reversing hypoxic cell chemoresistance in vitro using genetic and small molecule approaches targeting hypoxia inducible factor-1. Mol Pharmacol 2006;69:411-8.

6. Dai S, Huang ML, Hsu CY, Chao KS. Inhibition of hypoxia inducible factor 1alpha causes oxygen-independent cytotoxicity and induces p53 independent apoptosis in glioblastoma cells. Int J Radiat Oncol Biol Phys 2003;55:1027-36.

7. Ravizza R, Molteni R, Gariboldi MB, Marras E, Perletti G, Monti E. Effect of HIF-1 modulation on the response of two- and three-dimensional cultures of human colon cancer cells to 5-fluorouracil. Eur J Cancer 2009;(45):890-8.

8. Song X, Liu X, Chi W, Liu Y, Wei L, Wang X, Yu J. Hypoxia-induced resistance to cisplatin and doxorubicin in non-small cell lung cancer is inhibited by silencing of HIF-1alpha gene. Cancer Chemother Pharmacol 2006;58:776-84.

9. Sullivan R, Paré GC, Frederiksen LJ, Semenza GL, Graham CH. Hypoxia-induced resistance to anticancer drugs is associated with decreased senescence and requires hypoxia-inducible factor-1 activity. Mol Cancer Ther 2008;7:1961-73.

10. Yokoi K, Fidler IJ. Hypoxia increases resistance of human pancreatic cancer cells to apoptosis induced by gemcitabine. Clin Cancer Res 2004; 10:2299-306.

11. Kalra R, Jones AM, Kirk J, Adams GE, Stratford IJ. The effect of hypoxia on acquired drug resistance and response to epidermal growth factor in Chinese hamster lung fibroblasts and human breast-cancer cells in vitro. Int J Cancer 1993;54:650-5.

12. Peng X-H, Karna P, Cao Z, Jiang B-H, Zhou M, Yang L. Cross-talk between epidermal growth factor receptor and hypoxia-inducible factor-1alpha signal pathways increases resistance to apoptosis by up-regulating survivin gene expression. J Biol Chem 2006;281:25903-14.

13. Chang Q, Qin R, Huang T, Gao J, Feng Y. Effect of antisense hypoxiainducible factor 1 alpha on progression, metastasis, and chemosensitivity of pancreatic cancer. Pancreas 2006;32:297-305.

14. Hu Y, Kirito K, Yoshida K, Mitsumori T, Nakajima K, Nozaki Y, Hamanaka S, Nagashima T, Kunitama M, Sakoe K, Komatsu N. Inhibition of hy- 
poxia-inducible factor-1 function enhances the sensitivity of multiple myeloma cells to melphalan. Mol Cancer Ther 2009;8:2329-38.

15. Hussein D, Estlin EJ, Dive C, Makin GW. Chronic hypoxia promotes hypoxia-inducible factor-1alpha-dependent resistance to etoposide and vincristine in neuroblastoma cells. Mol Cancer Ther 2006;5:2241 50.

16. Jianrui S, Zengqiang Q, Xianling G, Qiudong Z, Xue Z, Lu G, Kai S, Feng $S$, Mengchao W, Lixin W. Hypoxia-induced autophagy contributes to the chemoresistance of hepatocellular carcinoma cells. Autophagy 2009;5:1131-44

17. Koch S, Mayer F, Honecker F, Schittenhelm M, Bokemeyer C. Efficacy of cytotoxic agents used in the treatment of testicular germ cell tumours under normoxic and hypoxic conditions in vitro. Br. J. Cancer 2003;89:2133-9

18. Chen J, Kobayashi M, Darmanin S, Qiao Y, Gully C, Zhao R, Yeung SC, Lee $\mathrm{MH}$. Pim-1 plays a pivotal role in hypoxia-induced chemoresistance. Oncogene 28(28):2581-92

19. Liu L, Ning X, Sun L, Zhang H, Shi Y, Guo C, Han S, Liu J, Sun S, Han Z, Wu K, Fan D. Hypoxia-inducible factor-1 alpha contributes to hypoxia-induced chemoresistance in gastric cancer. Cancer Sci. 2008;99(1):121-8

20. Wang J, Biju MP, Wang M-H, Haase VH, Dong Z. Cytoprotective effects of hypoxia against cisplatin-induced tubular cell apoptosis: involvement of mitochondrial inhibition and p53 suppression. J. Am. Soc. Nephrol. 2006;17:1875-85

21. Hao J, Song X, Song B, Liu Y, Wei L, Wang X, Yu J. Effects of lentivirusmediated HIF-1alpha knockdown on hypoxia-related cisplatin resistance and their dependence on p53 status in fibrosarcoma cells. Cancer Gene Ther. 2008; 15:449-55

22. Piret JP, Cosse JP, Ninane N, Raes M, Michiels C. Hypoxia protects HepG2 cells against etoposide-induced apoptosis VIA a HIF-1independent pathway. Exp. Cell Res. 2006;312:2908-20

23. Selvendiran K, Bratasz A, Kuppusamy ML, Tazi MF, Rivera BK, Kuppusamy P. Hypoxia induces chemoresistance in ovarian cancer cells by activation of signal transducer and activator of transcription 3. Int. J. Cancer 2009;125(9):2198-2204

24. Denko NC, Fontana LA, Hudson KM, Sutphin PD, Raychaudhur S, Altman R, Giaccia AJ. Investigating hypoxic tumor physiology through gene expression patterns. Oncogene 2003;22:5907-14

25. Sullivan R, Graham $\mathrm{CH}$. Hypoxia prevents etoposide-induced DNA damage in cancer cells through a mechanism involving hypoxiainducible factor 1. Mol. Cancer Ther. 2009;8:1702-13

26. Kilic M, Kasperczyk H, Fulda S, Debatin K-M. Role of hypoxia inducible factor-1 alpha in modulation of apoptosis resistance. Oncogene 2007;26:2027-38

27. Liu XW, Su Y, Zhu H, Cao J, Ding WJ, Zhao YC, He QJ, Yang B. HIF-1 adependent autophagy protects HeLa cells from fenretinide (4-HPR)induced apoptosis in hypoxia. Pharmacol. Res. 2010;62:416-25

28. Huang L, Ao Q, Zhang Q, Yang X, Xing H, Li F, Chen G, Zhou J, Wang S, Xu G, Meng L, Lu Y, Ma D. Hypoxia induced paclitaxel resistance in human ovarian cancers via hypoxia-inducible factor 1alpha. J. Cancer Res. Clin. Oncol. 2010;136:447-56

29. Roberts DL, Williams KJ, Cowen RL, Barathova M, Eustace AJ, Brittain Dissont S, Tilby MJ, Pearson DG, Ottley CJ, Stratford IJ, Dive C. Contribution of HIF-1 and drug penetrance to oxaliplatin resistance in hypoxic colorectal cancer cells. Br. J. Cancer 2009;101:1290-7

30. Sermeus A, Cosse J-P, Crespin M, Mainfroid V, de Longueville F, Ninane N, Raes M, Remacle J, Michiels C. Hypoxia induces protection against etoposide-induced apoptosis: molecular profiling of changes in gene expression and transcription factor activity. Mol. Cancer 2008;7:27

31. Dong Z, Venkatachalam MA, Wang J, Patel Y, Saikumar P, Semenza GL, Force T, Nishiyama J. Up-regulation of apoptosis inhibitory protein IAP-2 by hypoxia: HIF-1-independent mechanisms. J. Biol. Chem 2001:276:18702-9

32. Rohwer N, Cramer T. Hypoxia-mediated drug resistance: Novel insights on the functional interaction of HIFs and cell death pathways. Drug Resist. Updat. 2011;14:191-201

33. Schnitzer SE, Schmid T, Zhou J, Brüne B. Hypoxia and HIF-1alpha protect A549 cells from drug-induced apoptosis. Cell Death Differ. 2006;13(9):1611-13

34. Wang GL, Jiang BH, Rue EA, Semenza GL. Hypoxia-inducible factor 1 is a basic-helix-loop-helix-PAS heterodimer regulated by cellular O2 tension. Proc. Natl. Acad. Sci. U. S. A. 1995;92:5510-14
35. Yang Y, Karakhanova S, Werner J, Bazhin A V. Reactive oxygen species in cancer biology and anticancer therapy. Curr. Med. Chem. 2013;20:3677-92

36. Miyata T, Takizawa S, van Ypersele de Strihou C. Hypoxia. 1. Intracellular sensors for oxygen and oxidative stress: novel therapeutic targets. Am. J. Physiol. Cell Physiol. 2011;300:C226-C231

37. Hubbi ME, Hu H, Kshitiz, Ahmed I, Levchenko A, Semenza GL. Chaperone-mediated autophagy targets hypoxia-inducible factor$1 \beta$ (HIF- $1 \beta$ ) for lysosomal degradation. J. Biol. Chem. 2013;288:1070314

38. Semenza GL. Hypoxia-inducible factors in physiology and medicine. Cell 2012;148:399-408

39. Hung MC, Mills GB, Yu D. Oxygen sensor boosts growth factor signaling. Nat Med 2009;15(3):246-7

40. Huang LE. Carrot and stick: HIF-alpha engages c-Myc in hypoxic adaptation. Cell Death Differ. 2008;15:672-7

41. Yee Koh M, Spivak-Kroizman TR, Powis G. HIF-1 regulation: not so easy come, easy go. Trends Biochem. Sci. 2008;33(11):526-34

42. Tsai Y-P, Wu K-J. Hypoxia-regulated target genes implicated in tumor metastasis. J. Biomed. Sci. 2012;19:102

43. Semenza GL. Targeting HIF-1 for cancer therapy. Nat. Rev. Cancer 2003;3(10):721-32

44. Gu Y, Moran S, Hogenesch J, Wartman L, Bradfield C. Molecular characterization and chromosomal localization of a third alpha-class hypoxia inducible factor subunit, HIF3alpha. Gene Expr. 1998;7:20513

45. Hu C-J, Sataur A, Wang L, Chen H, Simon MC. The N-terminal transactivation domain confers target gene specificity of hypoxia-inducible factors HIF-1alpha and HIF-2alpha. Mol. Biol. Cell 2007;18:4528-42

46. Löfstedt $T$, Fredlund $E$, Holmquist-Mengelbier L, Pietras $A$ Ovenberger M, Poellinger L, Påhlman S. Hypoxia inducible factor2alpha in cancer. Cell Cycle 2007;6:919-26

47. Patel $\mathrm{S}$ a, Simon MC. Biology of hypoxia-inducible factor-2alpha in development and disease. Cell Death Differ. 2008;15(4):628-34

48. Wiesener MS, Ju JA, Warnecke C, Mandriota S, Bechmann I, Frei UA, Pugh CW, Eckardt K. Widespread hypoxia-inducible expression of HIF-2a in distinct cell populations of different organs. FASEB J. 2003; 17:271-3

49. Covello KL, Kehler J, Yu H, Gordan JD, Arsham AM, Hu C-J, Labosky PA, Simon MC, Keith B. HIF-2a regulates Oct-4: effects of hypoxiaon stem cell function, embryonic development, and tumor growth. Genes Dev. 2006;20:557-70

50. Helczynska K, Kronblad Å, Jögi A, Nilsson E, Beckman S, Landberg G, Påhlman S. Hypoxia promotes a dedifferentiated phenotype in ductal breast carcinoma in situ. Cancer Res. 2003:63:1441-4

51. Ghafar MA, Anastasiadis AG, Chen MW, Burchardt M, Olsson LE, Xie $\mathrm{H}$, Benson MC, Buttyan R. Acute hypoxia increases the aggressive characteristics and survival properties of prostate cancer cells. Prostate 2003;54:58-67

52. Påhlman S, Stockhausen MT, Fredlund E, Axelson H. Notch signaling in neuroblastoma. Semin. Cancer Biol. 2004;14:365-73

53. Gustafsson M V., Zheng X, Pereira T, Gradin K, Jin S, Lundkvist J, Ruas JL, Poellinger L, Lendahl U, Bondesson M. Hypoxia requires Notch signaling to maintain the undifferentiated cell state. Dev. Cell 2005;9:617-28

54. Shen G, Li X, Jia Y, Piazza G a, Xi Y. Hypoxia-regulated microRNAs in human cancer. Acta Pharmacol. Sin. 2013;34:336-41

55. Semenza GL. HIF-1 and tumor progression: Pathophysiology and therapeutics. Trends Mol. Med. 2002;8

56. Hartwich J, Orr WS, Ng CY, Spence Y, Morton C, Davidoff AM. HIF-1a activation mediates resistance to anti-angiogenic therapy in neuroblastoma xenografts. J. Pediatr. Surg. 2013;48(1):39-46

57. Bertout JA, Patel SA, Simon MC. The impact of $\mathrm{O} 2$ availability on human cancer. Nat. Rev. Cancer 2008;8:967-75

58. Cipro Š, Hřebačková J, Hraběta J, Poljaková J, Eckschlager T. Valproic acid overcomes hypoxia-induced resistance to apoptosis. Oncol. Rep. 2012;27(4):1219-26

59. Marikova $\mathrm{H}$. The significance of HIF-1 a transcription factor in neuroblastoma cell line (Diploma thesis). Institute of Chemical Technology in Prague; 2011:52-3

60. Adamski J, Price A, Dive C, Makin G. Hypoxia-Induced Cytotoxic Drug Resistance in Osteosarcoma Is Independent of HIF-1Alpha. PLoS One 2013;8(6) 
61. Yoshiba S, Ito D, Nagumo T, Shirota T, Hatori M, Shintani S. Hypoxia induces resistance to 5 -fluorouracil in oral cancer cells via G1 phase cell cycle arrest. Oral Oncol. 2009;45:109-15

62. Li DW, Dong P, Wang F, Chen XW, Xu CZ, Zhou L. Hypoxia induced multidrug resistance of laryngeal cancer cells via hypoxia-inducible factor-1a. Asian Pacific J. Cancer Prev. 2013;14:4853-8

63. Xuan Y, Hur H, Ham IH, Yun J, Lee JY, Shim W, Kim YB, Lee G, Han SU, Cho YK. Dichloroacetate attenuates hypoxia-induced resistance to 5 -fluorouracil in gastric cancer through the regulation of glucose metabolism. Exp. Cell Res. 2014;321:219-30

64. Frolova O, Samudio I, Benito J, Jacamo R, Kornblau SM, Markovic A Schober W, Lu H, Qiu YH, Buglio D, McQueen T, Pierce S, Shpall E, Konoplev S, Thomas D, Kantarjian H, Lock R, Andreeff M, Konopleva M. Regulation of HIF-1 a signaling and chemoresistance in acute lymphocytic leukemia under hypoxic conditions of the bone marrow microenvironment. Cancer Biol. Ther. 2012;13:858-70

65. Comerford KM, Wallace TJ, Karhausen J, Louis NA, Montalto MC Colgan SP. Hypoxia-inducible factor-1-dependent regulation of the multidrug resistance (MDR1) gene. Cancer Res. 2002;62:3387-94

66. Chen J, Ding Z, Peng Y, Pan F, Li J, Zou L, Zhang Y, Liang H. HIF-1a inhibition reverses multidrug resistance in colon cancer cells via downregulation of MDR1/P-Glycoprotein. PLoS One 2014;9

67. Zhang H, Bosch-Marce M, Shimoda LA, Yee ST, Jin HB, Wesley JB, Gonzalez FJ, Semenza GL. Mitochondrial autophagy is an HIF-1 dependent adaptive metabolic response to hypoxia. J. Biol. Chem. 2008;283:10892-903

68. Sermeus A, Michiels $C$. Reciprocal influence of the p53 and the hypoxic pathways. Cell Death Dis. 2011;2:e164

69. Zhou J, Brüne B. Cytokines and hormones in the regulation of hypoxia inducible factor-1alpha (HIF-1alpha). Cardiovasc. Hematol. Agents Med. Chem. 2006;4:189-97

70. Cramer T, Yamanishi Y, Clausen BE, Förster I, Pawlinski R, Mackman N, Haase VH, Jaenisch R, Corr M, Nizet V, Firestein GS, Gerber HP, Ferrara N, Johnson RS. HIF-1a is essential for myeloid cell-mediated inflammation. Cell 2003;112:645-57

71. Zhang HM, Cheung P, Yanagawa B, McManus BM, Yang DC. BNips: A group of pro-apoptotic proteins in the $\mathrm{BCl}-2$ family. Apoptosis 2003;8:229-36

72. Kothari S, Cizeau J, McMillan-Ward E, Israels SJ, Bailes M, Ens K, Kirshenbaum LA, Gibson SB. BNIP3 plays a role in hypoxic cell death in human epithelial cells that is inhibited by growth factors EGF and IGF. Oncogene 2003;22:4734-44

73. Blagosklonny M V, An WG, Romanova LY, Trepel J, Fojo T, Neckers L. p53 inhibits hypoxia-inducible factor-stimulated transcription. J. Biol. Chem. 1998;273:11995-8

74. Ravi R, Mookerjee B, Bhujwalla ZM, Sutter CH, Artemov D, Zeng Q, Dillehay LE, Madan A, Semenza GL, Bedi A. Regulation of tumor angiogenesis by $\mathrm{p} 53$-induced degradation of hypoxia-inducible factor 1alpha. Genes Dev 2000;14:34-44

75. Obacz J, Pastorekova S, Vojtesek B, Hrstka R. Cross-talk between HIF and p53 as mediators of molecular responses to physiological and genotoxic stresses. Mol. Cancer 2013;12:93

76. Qi H, Ohh M. The von Hippel-Lindau tumor suppressor protein sensitizes renal cell carcinoma cells to tumor necrosis factor-induced cytotoxicity by suppressing the nuclear factor-kappaB-dependent antiapoptotic pathway. Cancer Res. 2003;63:7076-80

77. Cosse J-P, Ronvaux M, Ninane N, Raes MJ, Michiels C. Hypoxiainduced decrease in p53 protein level and increase in c-jun DNA binding activity results in cancer cell resistance to etoposide. Neoplasia 2009;11:976-86

78. Duoduo W, Qionghua Z, Xiayan Z, Lei Z, Qiaojun H, Bo Y. Hypoxia promotes etoposide (VP-16) resistance in neuroblastoma CHP126 cells. Pharmazie 2010;65:51-6

79. Zhang L, Hill RP. Hypoxia enhances metastatic efficiency by up-regulating Mdm2 in KHT cells and increasing resistance to apoptosis. Cancer Res. 2004;64:4180-9

80. Arsham AM, Plas DR, Thompson CB, Simon MC. Akt and hypoxiainducible factor-1 independently enhance tumor growth and angiogenesis. Cancer Res. 2004;64:3500-7

81. Mizukami Y, Li J, Zhang X, Zimmer MA, Iliopoulos O, Chung DC. Hypoxia-Inducible Factor-1-Independent Regulation of Vascular Endothelial Growth Factor by Hypoxia in Colon Cancer. Cancer Res. 2004;64:1765-72
82. Coffey RN, Morrissey C, Taylor CT, Fitzpatrick JM, Watson RW. Resistance to caspase-dependent, hypoxia-induced apoptosis is not hypoxia-inducible factor-1 alpha mediated in prostate carcinoma cells. Cancer 2005;103:1363-74

83. Rohwer N, Dame C, Haugstetter A, Wiedenmann B, Detjen K, Schmitt CA, Cramer T. Hypoxia-inducible factor 1alpha determines gastric cancer chemosensitivity via modulation of p53 and NF-kappaB. PLoS One 2010;5:e12038

84. Boller YC, Brandes LM, Russell RL, Lin ZP, Patierno SR, Kennedy KA. Prostaglandin A1 inhibits stress-induced NF-kappaB activation and reverses resistance to topoisomerase II inhibitors. Oncol. Res. 2000;12:383-95

85. Rius J, Guma M, Schachtrup C, Akassoglou K, Zinkernagel AS, Nizet V, Johnson RS, Haddad GG, Karin M. NF-kappaB links innate immunity to the hypoxic response through transcriptional regulation of HIF1alpha. Nature 2008;453:807-11

86. Qiao L, Zhang H, Yu J, Francisco R, Dent P, Ebert MP, Röcken C, Farrell G. Constitutive activation of NF-kappaB in human hepatocellular carcinoma: evidence of a cytoprotective role. Hum. Gene Ther. 2006;17:280-90

87. Fan C, Li Q, Ross D, Engelhardt JF. Tyrosine phosphorylation of kappa B alpha activates NF kappa B through a redox-regulated and c-Src-dependent mechanism following hypoxia/reoxygenation. J. Biol. Chem. 2003;278:2072-80

88. Karin M, Ben-Neriah Y. Phosphorylation meets ubiquitination: the control of NF-[kappa]B activity. Annu. Rev. Immunol. 2000;18:621-63

89. Takahashi Y, Ganster RW, Gambotto A, Shao L, Kaizu T, Wu T, Yagnik GP, Nakao A, Tsoulfas G, Ishikawa T, Okuda T, Geller DA, Murase N. Role of NF-kappaB on liver cold ischemia-reperfusion injury. Am. J. Physiol. Gastrointest. Liver Physiol. 2002;283:G1175-84

90. Shishodia S, Aggarwal BB. Nuclear factor-kappaB activation: a question of life or death. J. Biochem. Mol. Biol. 2002;35:28-40

91. Li F, Huang L, Su X-L, Gu Q-H, Hu C-P. Inhibition of nuclear factor$\mathrm{KB}$ activity enhanced chemosensitivity to cisplatin in human lung adeno-carcinoma A549 cells under chemical hypoxia conditions. Chin. Med. J. (Engl). 2013;126(17):3276-82

92. Qanungo S, Wang M, Nieminen A-L. N-Acetyl-L-cysteine enhances apoptosis through inhibition of nuclear factor-kappaB in hypoxic murine embryonic fibroblasts. J. Biol. Chem. 2004;279:50455-64

93. Mattson MP, Meffert MK. Roles for NF-kappaB in nerve cell survival, plasticity, and disease. Cell Death Differ. 2006;13:852-60

94. Campbell KJ, Rocha S, Perkins ND. Active repression of antiapoptotic gene expression by RelA(p65) NF-kappaB. Mol. Cell 2004;13:853-65

95. Lee BL, Lee HS, Jung J, Cho SJ, Chung H-Y, Kim WH, Jin Y-W, Kim CS, Nam SY. Nuclear factor-kappaB activation correlates with better prognosis and Akt activation in human gastric cancer. Clin. Cancer Res. 2005;11:2518-25

96. Bonello S, Zähringer C, BelAiba RS, Djordjevic T, Hess J, Michiels C, Kietzmann T, Görlach A. Reactive oxygen species activate the HIF-1alpha promoter via a functional NFkappaB site. Arterioscler. Thromb. Vasc. Biol. 2007;27:755-61

97. Belaiba RS, Bonello S, Zähringer C, Schmidt S, Hess J, Kietzmann T, Görlach A. Hypoxia up-regulates hypoxia-inducible factor-1alpha transcription by involving phosphatidylinositol 3-kinase and nuclear factor kappaB in pulmonary artery smooth muscle cells. Mol. Biol. Cell 2007;18:4691-7

98. Cummins EP, Berra E, Comerford KM, Ginouves A, Fitzgerald KT, Seeballuck F, Godson C, Nielsen JE, Moynagh P, Pouyssegur J, Taylor CT. Prolyl hydroxylase- 1 negatively regulates IKB kinase- $\beta$, giving insight into hypoxia-induced NFKB activity. Proc. Natl. Acad. Sci. U. S. A. 2006;103:18154-9

99. Cerella C, Sobolewski C, Chateauvieux S, Henry E, Schnekenburger M, Ghelfi J, Dicato M, Diederich M. COX-2 inhibitors block chemotherapeutic agent-induced apoptosis prior to commitment in hematopoietic cancer cells. Biochemical Pharmacology.Vol 82.; 2011:1277-90

100. Chen C, Shen HL, Yang J, Chen QY, Xu WL. Preventing chemoresistance of human breast cancer cell line, MCF-7 with celecoxib. J. Cancer Res. Clin. Oncol. 2011;137:9-17

101. Hoang B, Zhu L, Shi Y, Frost P, Yan H, Sharma S, Sharma S, Goodglick $\mathrm{L}$, Dubinett $\mathrm{S}$, Lichtenstein A. Oncogenic RAS mutations in myeloma cells selectively induce cox-2 expression, which participates in enhanced adhesion to fibronectin and chemoresistance. Blood 2006;107:4484-90 
102. Saikawa Y, Sugiura T, Toriumi F, Kubota T, Suganuma K, Isshiki S, Otani Y, Kumai K, Kitajima M. Cyclooxygenase-2 gene induction causes CDDP resistance in colon cancer cell line, HCT-15. Anticancer Res. 2004;24:2723-8

103. Johann AM, Weigert A, Eberhardt W, Kuhn A-M, Barra V, von Knethen A, Pfeilschifter JM, Brüne B. Apoptotic cell-derived sphingosine1-phosphate promotes HuR-dependent cyclooxygenase-2 mRNA stabilization and protein expression. J. Immunol. 2008;180:1239-48

104. Billich A, Bornancin F, Mechtcheriakova D, Natt F, Huesken D, Baumruker T. Basal and induced sphingosine kinase 1 activity in A549 carcinoma cells: function in cell survival and IL-1 beta and TNFalpha induced production of inflammatory mediators. Cell. Signal. 2005; 17:1203-17

105. Paugh BS, Paugh SW, Bryan L, Kapitonov D, Wilczynska KM, Gopalan SM, Rokita H, Milstien S, Spiegel S, Kordula T. EGF regulates plas minogen activator inhibitor-1 (PAl-1) by a pathway involving c-Src PKCdelta, and sphingosine kinase 1 in glioblastoma cells. FASEB J. 2008;22:455-65

106. Schnitzer SE, Weigert A, Zhou J, Brüne B. Hypoxia enhances sphingosine kinase 2 activity and provokes sphingosine-1-phosphatemediated chemoresistance in A549 lung cancer cells. Mol. Cancer Res. 2009;7:393-401

107. Fresno Vara JA, Casado E, de Castro J, Cejas P, Belda-Iniesta C, González-Barón M. PI3K/Akt signalling pathway and cancer. Cancer Treat. Rev. 2004;30:193-204

108. Demaria M, Giorgi C, Lebiedzinska M, Esposito G, D’angeli L, Bartoli A, Gough DJ, Turkson J, Levy DE, Watson CJ, Wieckowsk MR, Provero P, Pinton P, Poli V. A STAT3-mediated metabolic switch is involved in tumour transformation and STAT3 addiction. Aging (Albany. NY). 2010;2:823-42

109. Xu Q, Briggs J, Park S, Niu G, Kortylewski M, Zhang S, Gritsko T, Turkson J, Kay H, Semenza GL, Cheng JQ, Jove R, Yu H. Targeting Stat3 blocks both HIF-1 and VEGF expression induced by multiple oncogenic growth signaling pathways. Oncogene 2005;24:5552-60

110. Barton BE, Karras JG, Murphy TF, Barton A, Huang HF-S. Signal transducer and activator of transcription 3 (STAT3) activation in prostate cancer: Direct STAT3 inhibition induces apoptosis in prostate cance lines. Mol. Cancer Ther. 2004;3:11-20

111. Burdelya L, Catlett-Falcone R, Levitzki A, Cheng F, Mora LB, Sotomayor E, Coppola D, Sun J, Sebti S, Dalton WS, Jove R, Yu H. Combination therapy with AG-490 and interleukin 12 achieves greater antitumor effects than either agent alone. Mol. Cancer Ther 2002;1:893-9

112. Burke WM, Jin X, Lin HJ, Huang M, Liu R, Reynolds RK, Lin J. Inhibition of constitutively active Stat3 suppresses growth of human ovarian and breast cancer cells. Oncogene 2001;20:7925-34

113. Niu G, Wright $K L$, Huang $M$, Song $L$, Haura $E$, Turkson J, Zhang $S$, Wang T, Sinibaldi D, Coppola D, Heller R, Ellis LM, Karras J, Bromberg J, Pardoll D, Jove R, Yu H. Constitutive Stat3 activity up-regulates VEGF expression and tumor angiogenesis. Oncogene 2002;21:2000 8

114. Forsythe JA, Jiang BH, lyer NV, Agani F, Leung SW, Koos RD, Semenza GL. Activation of vascular endothelial growth factor gene transcription by hypoxia-inducible factor 1. Mol. Cell. Biol. 1996;16:4604-13

115. Shin J, Lee HJ, Jung DB, Jung JH, Lee HJ, Lee EO, Lee SG, Shim BS, Choi SH, Ko SG, Ahn KS, Jeong SJ, Kim SH. Suppression of STAT3 and HIF-1 Alpha mediates Anti-Angiogenic activity of Betulinic acid in Hypoxic PC-3 prostate cancer cells. PLoS One 2011;6

116. Oh MK, Park HJ, Kim NH, Park SJ, Park IY, Kim IS. Hypoxia-inducible factor-1 $a$ enhances haptoglobin gene expression by improving binding of STAT3 to the promoter. J. Biol. Chem. 2011;286:8857-65

117. Isaac M, Siu A, Jongstra J. The oncogenic PIM kinase family regulates drug resistance through multiple mechanisms. Drug Resist. Updat. 2011;14(4-5):203-11

118. Cohen AM, Grinblat B, Bessler H, Kristt D, Kremer A, Schwartz A Halperin M, Shalom S, Merkel D, Don J. Increased expression of the hPim-2 gene in human chronic lymphocytic leukemia and nonHodgkin lymphoma. Leuk Lymphoma 2004;45:951-5

119. Chen WW, Chan DC, Donald C, Lilly MB, Kraft AS. Pim family kinases enhance tumor growth of prostate cancer cells. Mol. Cancer Res. 2005;3:443-51

120. Swords R, Kelly K, Carew J, Nawrocki S, Mahalingam D, Sarantopoulos J, Bearss D, Giles F. The Pim Kinases: New Targets for Drug Development. Curr. Drug Targets 2011;12:2059-66
121. Nawijn MC, Alendar A, Berns A. For better or for worse: the role of Pim oncogenes in tumorigenesis. Nat. Rev. Cancer 2011;11:23-34

122. Domingo-Domenech J, Oliva C, Rovira A, Codony-Servat J, Bosch M, Filella X, Montagut C, Tapia M, Campás C, Dang L, Rolfe M, Ross JS, Gascon P, Albanell J, Mellado B. Interleukin 6, a nuclear factor-KB target, predicts resistance to docetaxel in hormone-independent prostate cancer and nuclear factor-KB inhibition by PS-1145 enhances docetaxel antitumor activity. Clin. Cancer Res. 2006;12:557886

123. Valdman A, Fang X, Pang S-T, Ekman P, Egevad L. Pim-1 expression in prostatic intraepithelial neoplasia and human prostate cancer. Prostate 2004;60:367-71

124. Amaravadi R, Thompson CB. The survival kinases Akt and Pim as potential pharmacological targets. J. Clin. Invest. 2005;115(10):261824

125. Wang Z, Bhattacharya N, Mixter PF, Wei W, Sedivy J, Magnuson NS. Phosphorylation of the cell cycle inhibitor p21Cip1/WAF1 by Pim-1 kinase. Biochim. Biophys. Acta - Mol. Cell Res. 2002;1593:45-55

126. Winn LM, Lei W, Ness SA. Pim-1 phosphorylates the DNA binding domain of c-Myb. Cell Cycle 2003;2:258-62

127. Yan B, Zemskova M, Holder S, Chin V, Kraft A, Koskinen PJ, Lilly M. The PIM-2 Kinase Phosphorylates BAD on Serine 112 and Reverses BAD-induced Cell Death. J. Biol. Chem. 2003;278:45358-67

128. Aho TL, Sandholm J, Peltola KJ, Mankonen HP, Lilly M, Koskinen PJ. Pim-1 kinase promotes inactivation of the pro-apoptotic Bad protein by phosphorylating it on the Ser 112 gatekeeper site. FEBS Lett. 2004;571:43-9

129. Zippo A, De Robertis A, Bardelli M, Galvagni F, Oliviero S. Identification of Flk-1 target genes in vasculogenesis: Pim-1 is required for endothelial and mural cell differentiation in vitro. Blood 2004; 103:4536-44

130. Zippo A, De Robertis A, Serafini R, Oliviero S. PIM1-dependent phosphorylation of histone $\mathrm{H} 3$ at serine 10 is required for MYCdependent transcriptional activation and oncogenic transformation. Nat. Cell Biol. 2007;9:932-44

131. Morishita D, Katayama R, Sekimizu K, Tsuruo T, Fujita N. Pim kinases promote cell cycle progression by phosphorylating and downregulating $\mathrm{p} 27 \mathrm{kip} 1$ at the transcriptional and posttranscriptional levels. Cancer Res. 2008;68(13):5076-85

132. Nihira K, Ando Y, Yamaguchi T, Kagami Y, Miki Y, Yoshida K. Pim-1 controls NF-kappaB signalling by stabilizing RelA/p65. Cell Death Differ. 2010;17:689-98

133. Kim J, Roh M, Abdulkadir SA. Pim 1 promotes human prostate cancer cell tumorigenicity and c-MYC transcriptional activity. BMC Cancer 2010;10:248

134. Xie Y, Burcu M, Linn DE, Qiu Y, Baer MR. Pim-1 kinase protects P-glycoprotein from degradation and enables its glycosylation and cell surface expression. Mol. Pharmacol. 2010;78:310-18

135. Staab A, Loeffler J, Said HM, Diehlmann D, Katzer A, Beyer M, Fleischer M, Schwab F, Baier K, Einsele H, Flentje M, Vordermark D. Effects of HIF-1 inhibition by chetomin on hypoxia-related transcription and radiosensitivity in HT 1080 human fibrosarcoma cells. BMC Cancer 2007;7:213

136. Giatromanolaki A, Koukourakis MI, Sivridis E, Pastorek J, Wykoff CC, Gatter KC, Harris AL. Expression of hypoxia-inducible carbonic anhydrase-9 relates to angiogenic pathways and independently to poor outcome in non-small cell lung cancer. Cancer Res. 2001;61:7992-8

137. Kyndi M, Sørensen FB, Knudsen $H$, Alsner J, Overgaard M, Nielsen HM, Overgaard J. Carbonic anhydrase IX and response to postmastectomy radiotherapy in high-risk breast cancer: a subgroup analysis of the DBCG82 $b$ and c trials. Breast Cancer Res. 2008;10:R24

138. Frezza C, Zheng L, Tennant DA, Papkovsky DB, Hedley BA, Kalna G, Watson DG, Gottlieb E. Metabolic profiling of hypoxic cells revealed a catabolic signature required for cell survival. PLoS One 2011;6

139. Ferreira LM. Cancer metabolism: The Warburg effect today. Exp. Mol. Pathol. 2010;89:372-80

140. Semenza GL. Oxygen homeostasis. Wiley Interdiscip. Rev. Syst. Biol. Med. 2010;2:336-61

141. Zhou Y, Tozzi F, Chen J, Fan F, Xia L, Wang J, Gao G, Zhang A, Xia X Brasher H, Widger W, Ellis LM, Weihua Z. Intracellular ATP levels are a pivotal determinant of chemoresistance in colon cancer cells. Cancer Res. 2012;72:304-14

142. Skulachev VP. Bioenergetic aspects of apoptosis, necrosis and mitoptosis. Apoptosis 2006;11:473-85 
143. Vanlangenakker N, Vanden Berghe T, Krysko D V, Festjens N, Vandenabeele P. Molecular mechanisms and pathophysiology of necrotic cell death. Curr. Mol. Med. 2008;8:207-20

144. Fang M, Shen Z, Huang S, Zhao L, Chen S, MakTW, Wang X. The ER UDPase ENTPD5 promotes protein N-glycosylation, the Warburg effect, and proliferation in the PTEN pathway. Cell 2010;143:711-24

145. Papandreou I, Cairns RA, Fontana L, Lim AL, Denko NC. HIF-1 mediates adaptation to hypoxia by actively downregulating mitochondrial oxygen consumption. Cell Metab. 2006;3:187-97

146. Heddleston JM, Li Z, Lathia JD, Bao S, Hjelmeland AB, Rich JN. Hypoxia inducible factors in cancer stem cells. Br. J. Cancer 2010;102:789-95

147. Soeda A, Park M, Lee D, Mintz A, Androutsellis-Theotokis A, McKay RD, Engh J, Iwama T, Kunisada T, Kassam AB, Pollack IF, Park DM Hypoxia promotes expansion of the CD133-positive glioma stem cells through activation of HIF-1alpha. Oncogene 2009;28:3949-59

148. lida H, Suzuki M, Goitsuka R, Ueno H. Hypoxia induces CD133 expression in human lung cancer cells by up-regulation of OCT3/4 and SOX2. Int. J. Oncol. 2012;40:71-9

149. Hashimoto O, Shimizu K, Semba S, Chiba S, Ku Y, Yokozaki H, Hori Y. Hypoxia induces tumor aggressiveness and the expansion of CD133-positive cells in a hypoxia-inducible factor-1a-dependent manner in pancreatic cancer cells. Pathobiology 2011;78:181-92

150. Wu C-P, Du H-D, Gong H-L, Li D-W, Tao L, Tian J, Zhou L. Hypoxia promotes stem-like properties of laryngeal cancer cell lines by increasing the CD133+ stem cell fraction. Int. J. Oncol. 2014;44(5):1652-60

151. Zhu H, Wang D, Zhang L, Xie X, Wu Y, Liu Y, Shao G, Su Z. Upregulation of autophagy by hypoxia-inducible factor-1 a promotes EMT and metastatic ability of CD133+ pancreatic cancer stem-like cells during intermittent hypoxia. Oncol. Rep. 2014;32(3):935-42

152. Matsumoto K, Arao T, Tanaka K, Kaneda H, Kudo K, Fujita Y, Tamura D, Aomatsu K, Tamura T, Yamada Y, Saijo N, Nishio K. mTOR signa and hypoxia-inducible factor-1 a regulate CD133 expression in cancer cells. Cancer Res. 2009;69:7160-4

153. Ghattass K, Assah R, El-Sabban M, Gali-Muhtasib H. Targeting hypoxia for sensitization of tumors to radio- and chemotherapy. Curr. Cancer Drug Targets 2013;13:670-85

154. Hu M, Xing L, Mu D, Yang W, Yang G, Kong L, Yu J. Hypoxia imaging with 18F-fluoroerythronitroimidazole integrated PET/CT and immunohistochemical studies in non-small cell lung cancer. Clin. Nucl. Med. 2013;38:591-6

155. Jeong W, Rapisarda A, Park SR, Kinders RJ, Chen A, Melillo G, Turkbey B, Steinberg SM, Choyke P, Doroshow JH, Kummar S. Pilot trial of EZN-2968, an antisense oligonucleotide inhibitor of hypoxia-inducible factor-1 alpha (HIF-1a), in patients with refractory solid tumors. Cancer Chemother. Pharmacol. 2014;73:343-8

156. Kummar S, Raffeld M, Juwara L, Horneffer Y, Strassberger A, Allen D, Steinberg SM, Rapisarda A, Spencer SD, Figg WD, Chen X, Turkbey IB, Choyke P, Murgo AJ, Doroshow JH, Melillo G. Multihistology, target-driven pilot trial of oral topotecan as an inhibitor of hypoxia-inducible factor-1a in advanced solid tumors. Clin. Cancer Res. 2011;17:5123-31

157. Sooriakumaran $P$, Coley HM, Fox SB, Macanas-Pirard P, Lovell DP, Henderson A, Eden CG, Miller PD, Langley SEM, Laing RW. $A$ randomized controlled trial investigating the effects of celecoxib in patients with localized prostate cancer. Anticancer Res. 2009;29:1483-8

158. Weiss GJ, Infante JR, Chiorean EG, Borad MJ, Bendell JC, Molina JR Tibes R, Ramanathan RK, Lewandowski K, Jones SF, Lacouture ME, Langmuir VK, Lee H, Kroll S, Burris HA. Phase 1 Study of the Safety, Tolerability, and Pharmacokinetics of TH-302, a Hypoxia-Activated Prodrug, in Patients with Advanced Solid Malignancies.; 2011:29973004

159. Moen I, Stuhr LE. Hyperbaric oxygen therapy and cancer - a review. Target. Oncol. 2012;7:233-42

160. Suzuki Y, Tanaka K, Negishi D, Shimizu M, Yoshida Y, Hashimoto T, Yamazaki H. Pharmacokinetic investigation of increased efficacy against malignant gliomas of carboplatin combined with hyperbaric oxygenation. Neurol. Med. Chir. (Tokyo). 2009;49:193-7

161. Ohguri T, Imada H, Narisada H, Yahara K, Morioka T, Nakano K, Miyaguni Y, Korogi Y. Systemic chemotherapy using paclitaxel and carboplatin plus regional hyperthermia and hyperbaric oxygen treatment for non-small cell lung cancer with multiple pulmonary metastases: preliminary results. Int. J. Hyperthermia 2009;25:160-7

162. Mayer R, Hamilton-Farrell MR, Van Der Kleij AJ, Schmutz J, Granström G, Sicko Z, Melamed Y, Carl UM, Hartmann KA, Jansen EC, Ditri L, Sminia P. Hyperbaric oxygen and radiotherapy. Strahlentherapie und Onkol. 2005;181:113-23 